\title{
Observação da Narrativa Oral (LIBRAS/Português) de Sujeitos Surdos.
}

\author{
Karoline Baron de Lima (IC), Ivani Rodrigues Silva (PQ).
}

\section{Resumo}

Com o crescente reconhecimento da Libras como língua natural para os surdos, os mesmos vêm conquistando nos dias atuais o direito de serem considerados sujeitos bilíngues. Nesta pesquisa, por meio da observação da narrativa oral, seja em Libras ou em Português, verificamos que os sujeitos surdos se utilizam de mudança de códigos, se utilizam das marcas estruturais da narrativa, além disso, verificamos que há diferenças e semelhanças entre diferentes faixas etárias estudadas.

Palavras Chave: Narrativas Orais, Mudança de Código, Alunos Surdos.

\section{Introdução}

Com o crescente reconhecimento da Língua de Sinais, os surdos conquistam dia após dia a imagem de sujeitos bilíngues, por terem a Libras (Língua Brasileira de Sinais) como sua primeira língua - a mais acessível - e o Português, seja oral ou escrito, como segunda língua e principal forma de comunicação com os ouvintes (SILVA, 2008) ${ }^{1}$. Deve-se destacar que um importante fenômeno característico de sujeitos bilíngues é a mudança de códigos, que de acordo Grosjean (2010, p.4) citado por Bullio (2012)² é o momento em que o sujeito alterna a língua utilizada conforme seu interlocutor, ou a situação em que se encontra. Dentro desta perspectiva, notou-se a importância de observar a narrativa oral desses sujeitos a fim de verificar as características apresentadas nessa forma de comunicação.

Essa pesquisa teve como objetivos observar (a) a iniciação da narrativa, (b) o desenvolvimento e finalização da narrativa, (c) se os sujeitos surdos utilizavam da mudança de código em situação narrativa, e (d) se existiam diferenças e semelhanças entre as faixas etárias estudadas.

\section{Resultados e Discussão}

Os principais achados até o momento, assim como esperado, foram diferenças nas características narrativas entre as faixas etárias e níveis de escolaridade, ressaltando que foram utilizadas três faixas etárias - 5 a 10/ 10 a 15/ 15 a 20 anos. No grupo de menor idade os sujeitos não utilizaram das marcas convencionais da narrativa ao iniciarem suas narrativas, assim como não descreveram e encadearam os fatos da história, nos outros dois grupos de surdos mais velhos todos os sujeitos utilizaram das marcas congeladas da narrativa. Nas três faixas etárias os surdos que tem maior domínio do Português utilizaram essa língua durante a narrativa para diferentes objetivos.
Conclui-se que quanto maior o domínio de uma língua, seja Libras ou o Português, mais os sujeitos surdos conseguem ter domínio da estrutura narrativa, seja ela na forma oral ou em Libras. Esse maior domínio da estrutura canônica da narrativa acompanha a faixa etária dos sujeitos, o que sugere que a escolarização tem grande influência nesse aspecto. Também foi observado que a mudança de código está presente na vida dos sujeitos surdos bilíngues, independente da idade, e mesmo que o sujeito faça maior uso da Libras, algumas vezes, ele pode se apoiar no Português ao se comunicar com ouvintes.

\section{Agradecimentos}

Gostaria de agradecer ao $\mathrm{PIBIC} / \mathrm{CNPq}$ pela participação no Programa Institucional de Bolsas de Iniciação Científica - PIBIC/CNPq.

Assim como, gostaria de agradecer aos participantes da pesquisa e a minha orientadora Profa. Dra. Ivani Rodrigues Silva.

\footnotetext{
${ }^{1}$ SILVA, Ivani Rodrigues. Quando ele fica bravo, o português sai direitinho; fora disso a gente não entende nada: o contexto multilíngue da surdez e o (re)conhecimento das línguas no seu entorno. Trab. Ling. Aplic., Campinas, 47(2): 393 - 407, Jul./Dez. 2008.

BULLIO, Paula Cristina. Questões de Subjetividade em uma Criança Bilíngue. In: $\mathrm{Na}$ Língua do Outro: Estudos Interdisciplinares em Aquisição de Linguagens. Alessandra Del Ré \& Márcia Romero (organizadoras.), São Paulo: Cultura Acadêmica, 2012.
} 